\title{
XENOBIOTICS ENHANCE LACCASE ACTIVITY IN ALKALI-TOLERANT $\gamma$-PROTEOBACTERIUM JB
}

\author{
Gursharan Singh $^{1}$; Mona Batish ${ }^{1}$; Prince Sharma ${ }^{1 *}$; Neena Capalash ${ }^{2}$ \\ ${ }^{1}$ Department of Microbiology Panjab University, Chandigarh 160014, India; ${ }^{2}$ Department of Biotechnology, Panjab \\ University, Chandigarh 160014, India
}

Submitted: October 13, 2007; Returned to authors for corrections: January 28, 2008; Approved: February 15, 2009.

\begin{abstract}
Various genotoxic textile dyes, xenobiotics, substrates $(10 \mu \mathrm{M})$ and agrochemicals $(100 \mu \mathrm{g} / \mathrm{ml})$ were tested for enhancement of alkalophilic laccase activity in $\gamma$-proteobacterium JB. Neutral Red, Indigo Carmine, Naphthol Base Bordears and Sulphast Ruby dyes increased the activity by 3.7, 2.7, 2.6 and 2.3 fold respectively. Xenobiotics/substrates like $p$-toluidine, 8-hydroxyquinoline and anthracine increased it by 3.4, 2.8 and 2.3 fold respectively. Atrazine and trycyclozole pesticides enhanced the activity by 1.95 and 1.5 fold respectively.
\end{abstract}

Keywords: $\gamma$-proteobacterium, laccase, xenobiotics, dyes, agrochemicals

\section{INTRODUCTION}

Laccases (benzenediol oxygen oxidoreductases, EC 1.10.3.2) are polyphenol oxidases that require $\mathrm{O}_{2}$ to oxidize phenols, polyphenols, aromatic amines and different non-phenolic substrates by one electron transfer resulting in the formation of reactive radicals (11). They are members of the multicopper protein family that has developed from small sized prokaryotic azurins to eukaryotic ceruloplasmin. Laccases are widely distributed in plants and fungi (4), where their involvement in melanin formation and in a variety of different, and sometimes contradictory, physiological functions like fungal morphogenesis, plant pathogenesis and fungal virulence has been frequently proposed (29). They also occur in prokaryotes e.g. Azospirillum lipoferum (12), Marinomonas mediterranea (22), Bacillus subtilis spore (14) and $\gamma$-proteobacterium JB $(2,24)$. Stimulation of laccase activity in fungi with respect to culture medium composition has been investigated by many workers. Filazzola et al. (10) reported the influence of xenobiotics on catalytic activity of constitutive forms of laccases. Metal ions and several organic molecules have also been assayed for their ability to enhance activity of inducible form of laccases $(25,29)$. Gallic and ferulic acids were used, mainly because of their structural analogy with lignin model compounds (11). Dyes that affect laccase synthesis include Ethidium Bromide, Malachite Green, Phenol Red and Thymol Blue $(7,15)$. Laccase induction in bacteria has not been studied before, although bacteria offer many advantages over fungi e.g. the faster multiplication rates resulting in early enzyme production. Fungi are usually acidophilic, while bacteria can inhabit acidophilic to alkalophilic environments making their enzymes more stable to $\mathrm{pH}$ (2). However, low levels of laccase activity in bacteria are not sufficient for commercial applications.

Our previous work (unpublished) showed that laccase in $\gamma$ proteobacterium JB played no role in melanin synthesis or protection from UV or oxidizing agents, though copper and some dyes induced laccase activity (15). This work shows that several xenobiotics induce laccase activity in this bacterium, isolated from industrial effluents, indicating the physiological role of laccase in protection from toxic environmental compounds in response to respiratory stress. The work will be useful for large scale production of laccase for various industrial applications. Laccases from bacteria are not common. Presently, only a few bacteria have been reported with laccase activity (24). This work is the first report on xenobiotics enhancing laccase activity in bacteria.

*Corresponding Author. Mailing address: Department of Microbiology, Panjab University, Chandigarh 160014, India. Tel.: 91-172-2534147 Fax: 91172-2541770. E-mail: princess@pu.ac.in 


\section{MATERIALS AND METHODS}

\section{Chemicals}

All chemicals used were of more than $90 \%$ purity. Textile dyes were obtained from JCT Textile Mill (India). Xenobiotics/substrates were from Sigma (USA) and HiMedia (India). Agrochemicals were commercially available in India. Dyes and other chemicals were soluble in water, dimethyl sulfoxide or $50 \%$ ethanol. Proper controls were put up for each solvent or chemical during laccase production or during evaluation of activity of this enzyme.

\section{Mutagenicity of dyes}

Mutagenicity of the dyes was determined by Ames (1) and rec (8) assays as described previously $(3,5)$. Ames test measures the frequency of reversal of his mutations in Salmonella typhimurium to is $^{+}$prototrophy by mutagens/carcinogens. $R e c$ assay measures the mutagenic/carcinogenic potential of a chemical by comparing the ability of recombination proficient $\left(\mathrm{rec}^{+}\right.$) and deficient ( $\mathrm{rec}^{-}$) strains of Bacillus subtilis to repair the DNA damage caused by that chemical.

\section{Organism and culture conditions for enzyme production}

$\gamma$-Proteobacterium JB was grown in M162 medium (6) at $37^{\circ} \mathrm{C}, 150 \mathrm{rpm}$ for $72 \mathrm{~h}$ after inoculation with $1 \%(\mathrm{v} / \mathrm{v})$ of $16-18 \mathrm{~h}$ pre-inoculum grown in same medium. The culture was centrifuged at $10000 \mathrm{~g}, 4^{\circ} \mathrm{C}$ for $10 \mathrm{~min}$ and the supernatant was used as extracellular enzyme prepration. Cell pellet was disrupted using a Braun Labsonic sonicator (4-5 bursts of 1 min each at $100 \%$ power). The cell extract was obtained by centrifugation at $13000 \mathrm{~g}, 4^{\circ} \mathrm{C}$ for $15 \mathrm{~min}$ and used as crude intracellular enzyme preparation. Dry weight of $72 \mathrm{~h}$ old culture was measured by centrifuging $20 \mathrm{ml}$ culture of $\gamma$-proteobacterium JB at $10000 \mathrm{~g}$ and drying the pellet at $50^{\circ} \mathrm{C}$ till constant weight. Viable cell count $(\mathrm{cfu} / \mathrm{ml})$ was measured by standard procedure. All experiments were carried out at least in triplicates. Laccase activities were determined $72 \mathrm{~h}$ after the onset of growth and conditions were kept identical for each compound like medium, shaking, $\mathrm{pH}$ and temperature.

\section{Enzyme assays}

Laccase activity was determined by measuring the oxidation of guaiacol at $465 \mathrm{~nm}$. The reaction mixture contained $2 \mathrm{mM}$ guaiacol and $50 \mathrm{mM}$ phosphate buffer ( $\mathrm{pH}$ 6.5). One unit was the amount of enzyme that increased the absorbance by 0.001 absorbance units per min at $55^{\circ} \mathrm{C}$. In all cases, initial rate of reaction was measured over $10 \mathrm{~min}$ (2). Assays for lignin peroxidase and manganese peroxidase were performed as described by Tien and Kirk (28).

\section{Statistical analyses}

Student's $t$-test was performed using SigmaStat ${ }^{\circledR}$ statistical software version 2.03 .

\section{RESULTS}

The organism used was Gram-negative, non-sporulating, non-hemolytic, singly occurring, short rod. It did not grow on McConkey and cetrimide agar and was oxidase positive but catalase, indole, methyl red, Voges-Proskauer, citrate negative. Growth on glucose was positive with no gas and no acid production. 16S rDNA sequencing of $\gamma$-proteobacterium JB was carried out previously in our laboratory (2). A BLASTn algorithm search of GenBank database (htt://www.ncbi.nlm.nih/BLAST) exhibited $98 \%$ identity with the closest match $\gamma$-proteobacterium F8 and the present organism was named $\gamma$-proteobacterium JB. The bacterium produced laccase but was not found to produce lignin peroxidase and manganese peroxidase enzymes even when tested in 100 times concentrated cell free supernatant and intracellular preparations.

\section{Effect of mutagenic dyes on laccase activity}

Laccase activity was enhanced on addition of some dyes in the culture medium (Table 1). Neutral Red, Indigo Carmine, Naphthol Base Bordears and Sulphast Ruby showed 3.7-, 2.7-, 2.6-, and 2.3 fold increase in activity. In the presence of Disperse Blue $\mathrm{D}_{2} \mathrm{R}$, no laccase activity was observed although it enhanced the growth of organism by 1.4 fold. Reactofix Golden Yellow, Navilene Brown and Navilene Orange reduced the enzyme activity by 2.6, 1.7 and 1.3 fold respectively. Navilene Yellow Brown, Fuschin and Crystal Violet increased laccase activity slightly but reduced growth.

\section{Effect of xenobiotics on laccase activity}

Ten aromatic xenobiotics were tested for laccase activity (Table 2). $p$-Toluidine induced (3.4 fold) the activity maximally, followed by 8 -hydroxyquinoline (2.8 fold), phthalic acid (2.1 fold), Tween-20 (2.0 fold), nicotinic acid (1.7 fold), 2,4,6trichlorophenol (1.7 fold) and dinitrosalicylic acid (1.48 fold). Veratric acid decreased the enzyme activity by 1.6 fold.

\section{Effect of substrates on laccase activity}

Anthracine increased the enzyme activity maximally by 2.3 fold (Table 3). Tyrosine, $p$-phenylenediamine and ferulic acid increased by $1.5,1.2$ and 1.1 fold respectively.

\section{Effect of agrochemicals on laccase activity}

Among the five agrochemicals tested (Table 4), atrazine and trycyclozole pesticides enhanced the enzyme activity by 1.95 and 1.5 fold respectively. Tebuconazole reduced the activity by 1.3 fold.

\section{DISCUSSION}

The results show that xenobiotics of environmental interest and natural products can increase the laccase activity in $\gamma$ - 
Table 1. Effect of dyes on laccase activity of $\gamma$-proteobacterium JB $72 \mathrm{~h}$ cultures.

\begin{tabular}{|c|c|c|c|c|c|}
\hline \multirow[b]{2}{*}{ Dye $(10 \mu \mathrm{M})$} & \multirow{2}{*}{$\begin{array}{l}\text { Functional/Structural } \\
\text { group/ CI No. }\end{array}$} & \multicolumn{2}{|c|}{ Mutagenicity of Dyes } & \multirow{2}{*}{$\begin{array}{c}\text { Growth } \\
\left(\text { g dry wt l-1/ }^{-1 /}\right. \\
\left.\text { Log cfu ml } l^{-1}\right)\end{array}$} & \multirow{2}{*}{$\begin{array}{l}\text { Laccase } \\
\text { activity } \\
\left(\mathrm{U} \mathrm{mg}^{-1}\right. \\
\text { dry wt) }\end{array}$} \\
\hline & & Ames test & rec assay & & \\
\hline None & & & & $0.25 / 9.2$ & 61.6 \\
\hline Indigo Carmine $\quad(\mathrm{W})$ & NA/Anthraquinone / 73015 & - & - & $0.085 / 8.9$ & 170.5 \\
\hline Naphthol Base Borders (D) & Naphthol / Anthraquinone / NA & $+\mathrm{F}$ & + & $0.12 / 8.9$ & 163.6 \\
\hline Sulphast Ruby (D) & Sulphur / Anthraquinone / NA & - & $+\mathrm{S} 9$ & $0.11 / 8.9$ & 142.7 \\
\hline Dispers Blue D2R (D) & Disperse / Anthraquinone / NA & $+\mathrm{F} / \mathrm{B}(\mathrm{S} 9)$ & $+\mathrm{S} 9$ & $0.35 / 9.3$ & N.D \\
\hline Navilene Yellow Brown (D) & Disperse / Anthraquinone / NA & $+\mathrm{F} / \mathrm{B}$ & $+\mathrm{S} 9$ & $0.095 / 8.9$ & 81.6 \\
\hline Navinon Brown (D) & Vat / Anthraquinone / 69015 & $+\mathrm{F}$ & & $0.245 / 9.2$ & 71 \\
\hline Sulphast Green (D) & Sulphur / Anthraquinone / NA & - & $+\mathrm{S} 9$ & $0.25 / 9.2$ & 62 \\
\hline Sulphur Niritaryl Green (D) & Sulphur / Anthraquinone / NA & - & $+\mathrm{S} 9$ & $0.3 / 9.2$ & 59.6 \\
\hline Reactofix Golden Yellow (W) & Reactive / Disazo / NA & $+F$ & $+\mathrm{S} 9$ & $0.34 / 9.3$ & 23.4 \\
\hline Malacryl Red (W) & Basic/Disazo / NA & - & + & $0.25 / 9.1$ & 58.4 \\
\hline Navilene Brown(D) & Disperse / Monoazo / NA & +F/B (S9) & $+\mathrm{S} 9$ & $0.25 / 9.1$ & 36 \\
\hline Navilene Orange (D) & Basic / Monoazo / NA & $+\mathrm{F} / \mathrm{B}$ & + & $0.25 / 9.1$ & 44.4 \\
\hline Neutral Red (W) & Basic / Heterocyclic /50040 & + & - & $0.25 / 9.1$ & 227 \\
\hline Fuschin $(\mathrm{W})$ & Acidic / Triphenylmethane / 42685 & + & - & $0.11 / 8.9$ & 81 \\
\hline Crystal Violet (W) & Basic / Triphenylmethane / 42555 & + & + & $0.175 / 9.1$ & 78 \\
\hline
\end{tabular}

W: water soluble

$\mathrm{F}$ : inducing frameshift mutations

CI NO: color Index no.

D: Dimethyl sulfoxide soluble

B: inducing base-pair substitutions

S9: $\operatorname{mix}(16)$

NA: Not available, ND: Not detectable. Student's t-test revealed that increase and reduction in laccase activity was significant $(\mathrm{p}<0.001)$ for all dyes except $\mathrm{p}=0.004$ and 0.29 for Navinon Brown and Sulphast Green, respectively when compared with non-treated controls.

Table 2. Effect of xenobiotics on laccase activity of $\gamma$ proteobacterium JB $72 \mathrm{~h}$ cultures.

\begin{tabular}{lcc}
\hline \multicolumn{1}{c}{$\begin{array}{c}\text { Xenobiotics } \\
(10 \mu \mathrm{M})\end{array}$} & $\begin{array}{c}\text { Growth } \\
\left(\mathrm{g} \mathrm{dry} \mathrm{wt} \mathrm{l}^{-1 /} /\right. \\
\left.\text { Log cfu ml }{ }^{-1}\right)\end{array}$ & $\begin{array}{c}\text { Laccase } \\
\text { activity } \\
\left(\mathrm{U} \mathrm{mg}^{-1} \text { dry wt }\right)\end{array}$ \\
\hline None $\quad 0.25 / 9.1$ & 61.6 & \\
2,4,6-Trichlorophenol(E) & $0.09 / 8.9$ & 106.1 \\
Aniline 0.11/8.9 & 70.1 & \\
Nicotinic acid (D) & $0.123 / 8.9$ & 106.3 \\
Phthalic acid (E) & $0.15 / 9.0$ & 133 \\
Dinitrosalicylic acid (W) & $0.27 / 9.1$ & 91.4 \\
8-Hydroxyquinoline (E) & $0.13 / 9.0$ & 175 \\
$p$-Toluidine (E) & $0.1 / 8.9$ & 213 \\
Tween-200.25/9.1 & 124.8 & \\
Veratric acid (E) & $0.3 / 9.2$ & 38.6 \\
Xylidine (w)0.1/8.9 & 84 & \\
\hline
\end{tabular}

E: 50\% ethanol soluble, D: Dimethylsulfoxide soluble, W: Water soluble Student's t-test revealed that increase and reduction in laccase activity was significant $(p<0.001)$ for all xenobiotics except aniline $(p=0.004)$.
Table 3. Effect of substrates on laccase activity of $\gamma$ proteobacterium JB $72 \mathrm{~h}$ cultures.

\begin{tabular}{lcc}
\hline \multicolumn{1}{c}{$\begin{array}{c}\text { Substrates } \\
(10 \mu \mathrm{M})\end{array}$} & $\begin{array}{c}\text { Growth } \\
\left(\mathrm{g} \mathrm{dry} \mathrm{wt} \mathrm{l}^{-1} /\right. \\
\text { Log cfu ml }\end{array}$ & $\begin{array}{c}\text { Laccase } \\
\text { activity } \\
\left(\mathrm{U} \mathrm{mg}^{-1} \text { dry wt }\right)\end{array}$ \\
\hline None & $0.21 / 9.1$ & 82 \\
Anthracine (D) & $0.15 / 9.0$ & 190 \\
Tyrosine (W) & $0.25 / 9.1$ & 125.3 \\
Ferulic acid (E) & $0.23 / 9.1$ & 93 \\
$p$-Phenylenediamine (W) & $0.3 / 9.2$ & 103 \\
\hline
\end{tabular}

E: $50 \%$ ethanol soluble, D: Dimethyl sulfoxide soluble, W: water soluble. Student's t-test revealed that increase in laccase activity was significant $(p<0.001)$ for all substrates except $\mathrm{p}=0.003$ for ferulic acid.

proteobacterium JB. Ethidium Bromide is the only dye reported to increase laccase activity in fungi and bacteria $(7,15)$. This prompted us to study the effect of various mutagenic dyes on laccase activity at subinhibitory concentrations. Among the dyes tested, one heterocyclic and many anthraquinone dyes 
enhanced laccase activity significantly. Dispers Blue $\mathrm{D}_{2} \mathrm{R}$ acted differently. Though it belongs structurally to anthraquinone group but reduced laccase activity to an undetectable level. In Indigo Carmine and Neutral Red, an amine group is common on the benzene rings. Increase in activity may be due to degradation/transformation products of these dyes formed during incubation for $72 \mathrm{~h}$, as laccase from this organism degraded Indigo Carmine to isatin and anthranilic acid (26). The impact of genotoxicity of these dyes on organism is not clearly understood. Enhanced activity of laccase in $\gamma$-proteobacterium JB could possibly be due to the respiratory stress induced in the cells (19). Xenobiotics may increase laccase activity by increasing the level of gene expression without affecting laccase isozyme composition. Veratric acid, an inducer in various fungi (18), could not increase laccase activity in $\gamma$-proteobacterium JB. $p$-Toluidine, phthalic acid and 2,4,6-trichlorophenol enhanced laccase activity, but decreased microbial growth. These one ring compounds have different substituted groups. Phthalic acid has two carboxylic groups; 2,4,6-trichlorophenol has three chloro groups, while toluidine contained one amino and one methyl group at para position (Fig. 1). Increase in

Table 4. Effect of agrochemicals on laccase activity of $\gamma$ proteobacterium JB $72 \mathrm{~h}$ cultures.

\begin{tabular}{lcc}
\hline $\begin{array}{c}\text { Agrochemicals } \\
(100 \mu \mathrm{g} / \mathrm{ml})\end{array}$ & $\begin{array}{c}\text { Growth } \\
\left(\mathrm{g} \mathrm{dry} \mathrm{wt}^{-1}\right) / \\
\left.\text { Log cfu ml }^{-1}\right)\end{array}$ & $\begin{array}{c}\text { Laccase } \\
\text { activity } \\
\left(\mathrm{U} \mathrm{mg}^{-1} \text { dry wt }\right)\end{array}$ \\
\hline None & $0.11 / 9.0$ & 108.6 \\
Atrazine (D) & $0.09 / 8.9$ & 211 \\
Carbendazine (D) & $0.1 / 8.9$ & 121 \\
Trycyclozole (D) & $0.1 / 8.9$ & 160 \\
Hexaconazole (D) & $0.13 / 9.2$ & 102 \\
Tebuconazole (D) & $0.11 / 9.1$ & 81.8 \\
\hline
\end{tabular}

D: Dimethyl sulfoxide soluble. Student's t-test revealed that increase and reduction in laccase activity was significant $(\mathrm{p}<0.001)$ for all agrochemicals except carbendazine $(\mathrm{p}=<0.002)$.

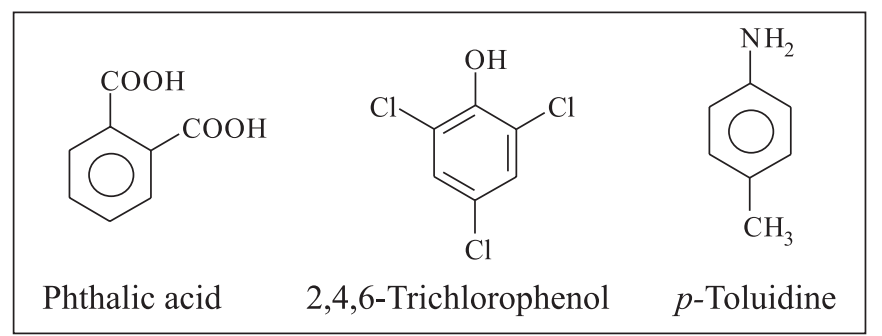

Figure 1. Laccase activity was enhanced by aromatic compounds of different structures. activity does not seem to be caused by specific structure/ substituent group. Xiao et al. (29) reported that compounds with different chemical structures affect composition of laccase isozymes in Trametes sp. AH28-2.

Aromatic compounds which increase laccase activity are very often toxic to fungal growth and metabolism, and it has been proposed that one of the possible functions of fungal laccase is the polymerization of toxic aromatic compounds. Therefore, laccase may function as a defence mechanism against oxidative stress. Fernandez-Larrea and Stahl (9) reported that oxidative stress, caused by aromatic compounds in Podospora anserina, typically was accompanied by the induction of laccase mRNA. Solden and Dobson (27) found that xenobiotic response elements (XREs) are present in the region upstream from promoter of lac 4 in Pleurotus sajor-caju, which are regulated by aromatic compounds. The XRE has a consensus sequence TNGCGTG, which is a cis-acting element sufficient to increase transcription of genes in eukaryotes by aromatic compounds (21). Cloning of the gene encoding laccase from $\gamma$ proteobacterium JB, especially promoter region, may help elucidate the mechanism of regulation of laccase activity by aromatic compounds. 8-Hydroxyquinoline is a known reducing agent but its role in increased laccase activity is not understood. On the other side, Tween-20 is a non toxic polysorbate used as a surfactant and is a known solubilizing agent of membrane proteins. It may not induce laccase, but may remove the bound laccase from cell membranes of $\gamma$-proteobacterium JB into broth. Third group of tested chemicals included various substrates, where anthracine showed maximum activity while ferulic acid did not, though it is known to increase laccase activity in fungi (13). Tested substrates were not oxidized by laccase (except $p$ phenylenediamine), may be due to the high redox potential (E $1 / 2$ ) of these compounds. The increased laccase activity in fungi by a number of low molecular weight phenolic compounds has been demonstrated at the physiological level $(20,23)$. This work is the first attempt dealing with enhancement of bacterial laccase activity using these substrates. Among the tested agrochemicals, only atrazine and trycyclozole increased laccase activity (Table 4). Mougin et al. (17) also reported stimulating effect of atrazine on laccase activity by $T$. versicolor. In order to investigate whether the increase in laccase activity by xenobiotic compounds resulted in synthesis of new laccase isozymes, native polyacrylamide gel electrophoresis (PAGE) was carried out. Protein bands exhibiting laccase activity were stained red with guaiacol $(2 \mathrm{mM})$ in $50 \mathrm{mM}$ phosphate buffer, pH 6.5. Native PAGE analysis of $\gamma$-proteobacterium JB laccase, in presence or absence of xenobiotics, revealed only one band in all cases (data not shown), which suggests that the effect on laccase activity was not due to new isozymes expression. Some conclusions can be drawn from our study. Additional efforts must be devoted to the optimisation of culture conditions to enhance the sensitivity of bacterial response to the treatment 
with xenobiotics. In such conditions, laccase could be used as biomarker to assess environmental contamination. Laccase producing fungi have also been reported to be useful tools for xenobiotics removal in liquid effluents as well as in soil bioremediation (25).

\section{RESUMO}

\section{Xenobióticos aumentam a atividade de lacase em $\gamma$-Proteobacterium JB alcali-tolerante}

Vários corantes têxteis genotóxicos, xenobióticos, substratos $(10 \mathrm{mM})$ e agroquímicos $(100 \mathrm{mM} / \mathrm{mL})$ foram testados quanto ao aumento da atividade de lacase em g-Proteobacterium JB. Os corantes Neutral Red, Indigo Carmine, Naphtol Base Bordears e Sulphast Ruby aumentaram a atividade em 3,7, 2,7, 2,6 e 2,3 vezes, respectivamente. Xenobióticos/substratos como $p$-toluidina, 8-hidroxiquinolina e antracina aumentaram a atividade em 3,4, 2,8 e 2,3 vezes, respectivamente. Atrazina e pesticidas triciclozol aumentaram a atividade em 1,95 e 1,5 vezes, respectivamente.

Palavras-chave: $\gamma$-Proteobacterium, lacase, xenobióticos, corantes, agroquímicos.

\section{REFERENCES}

1. Ames, B.N.; Lee, F.D.; Durston, W.E. (1973). An improved bacterial test system for the detection and classification of mutagens and carcinogens. Proc. Natl. Acad. Sci. U.S.A. 70: 782-786.

2. Bains, J.; Capalash, N.; Sharma, P.; (2003). Laccase from a non melanogenic,alkalotolerant $\gamma$-proteobacterium JB isolated from industrial waste water drained soil. Biotechnol. Lett. 25: 11551159.

3. Bakshi, D.K.; Sharma, P. (2003). Evaluation of genotoxicity of textile dyes with Ames test and rec-assay. J. Environ. Pathol. Toxicol. Oncol. 22: 101-109.

4. Cavallazzi, J.R.P.; Oliveira, M.G.A.; Kasuya, M.C.M. (2004). Laccase production by Lepista sordida. Braz. J. Microbiol. 35: 261-263.

5. Choudhary, E.; Capalash, N.; Sharma, P. (2004). Evaluation of mutagenicity of degradation products of textile dyes with rec assay after PhotoFenton and ligninase treatments. J. Environ. Pathol. Toxicol. Oncol. 23: 279-285.

6. Degryse, E.; Glansdorff, N.; Pierard, A. (1978). A comparative analysis of thermophilic bacteria belonging to the genus Thermus. Arch. Microbiol. 117: 189-196.

7. Dhawan, S.; Lal, R.; Kuhad, R.C. (2003). Ethidium bromide stimulated hyper laccase production from bird's nest fungus Cyathus bulleri. Lett. Appl. Microbiol. 36: 64-67.

8. Dubnau, D.; Abelson, B.S.; Ciriglian. (1973). Rate of transforming deoxyribonucleic acid uptake by competent Bacillus subtilis: Phenotypic characterization of radiation-sensitive recombinant deficient mutants. J. Bacteriol. 114(1): 273-286.

9. Fernandez-Larrea, J.; Stahl, U. (1996). Isolation and characterization of laccase gene from Podospora anserine. Mol. Gen. Genet. 252: $539-551$.
10. Filazzola, M.T.; Sannio, F.; Rao, M.A.; Gianfreda, L. (1999). Effect of various pollutants and soil-like constituents on laccase from Cerrena unicolor. J. Environ. Qual. 28: 1929-1938.

11. Gianfreda, L.; Xu F.; Bollag, J.M. (1999). Laccases: a useful group of oxidoreductive enzymes. Bioremediat. J. 3: 1-25.

12. Givaudan, A.; Effosse, A.; Faure, D.; Potier, P.; Bouillant, M.L.; Bally, R. (1993). Polyphenol oxidase from Azospirillum lipoferum isolated from rice rhizosphere: evidence of laccase activity in nonmotile strains of Azospirillum lipoferum. FEMS Microbiol. Lett. 108: 205-210.

13. Herpoel, I.; Jeller, H.; Fang, G.; Petit-Conil, M.; Bourbonnais, R.; Robert, J.L.; Asther, M.; Sigoillot, J.C. (2002). Efficient enzymatic delignification of wheat straw pulp by a sequential xylanase-laccase treatment. J. Pulp Paper Sci. 28: 67-71.

14. Hullo, M.F.; Moszer, I.; Danchin, A.; Martin-Verstraete. (2001). Cot A of Bacillus subtilis is a copper-dependent laccase. J. Bacteriol. 183: $5426-5430$.

15. Malhotra, K.; Sharma, P.; Capalash, N. (2004). Copper and dyes enhance laccase production in $\gamma$-proteobacterium JB. Biotechnol. Lett. 26: 1047-1050.

16. Maron, D.M.; Ames, B.N. (1983). Revised methods for the Salmonella mutagenicity test. Mutat. Res. 113: 173-215.

17. Mougin, C.; Albert, K.; Claude-Jolivalt., (2002). Enhanced production of laccase in the fungus Trametes versicolor by the addition of xenobiotics Biotechnol. Lett 24: 139-142.

18. Munoz, C., Guillen, A.T., Martinez, M.J. (1997). Induction and Characterization of laccase in the Ligninolytic fungus Pleurotus eryngi. Curr. Microbiol. 34: 15.

19. Perlman, P.S.; Mahler, H.R. (1971). A premutational state induced in yeast by Ethidium bromide. Biochem. Biophys. Res. Commun. 44: 261-267.

20. Renato, P.; Jose.; Catarina K.; Marcos S. (2005). Screening of inducers for laccase production by Lentinula edodes in liquid medium. Braz. J. Microbiol. 36: (4) 1-8.

21. Rushmore, T.H.; Morton, M.R.; Pickett, C.B. (1991). The antioxidant responsive element: activity by oxidative stress and identification of the DNA consensus sequence required for functional activity. J. Biol. Chem. 266: 11632-11639.

22. Sanchez-Amat, A.; Solano, F. (1997). A pluripotent polyphenol oxidase from the melanogenic marine Alteromonas SP. shares catalytic capabilities of tyrosinases and laccases. Biochem. Biophys. Res. Commun. 240: 787-792.

23. Sethuraman, A.; Akin, D.E.; Eisele, F.G.; Eriksson, K.E.L. (1998). Effect of aromatic compounds on growth and ligninolytic enzyme production of two white rot fungi Ceriporiopsis subvermispora and Cyathus stercoreus. Can. J. Microbiol. 44: 872-885.

24. Sharma, P.; Goel, R.; Capalash, N. (2007). Bacterial laccases. World J. Microbiol. Biotechnol. 23: 823-832.

25. Sheel, T.; Hofer, M.; Ludwig, S.; Holker, U. (2000). Differential expression of manganese peroxidase and laccase in white-rot fungi in the presence of manganese or aromatic compounds. Appl. Microbiol. Biotechnol. 54: 686-691.

26. Singh, G.; Capalash, N.; Goel, R.; Sharma, P. ( 2007). A pH-stable laccase from alkali-tolerant $\gamma$-proteobacterium JB: Purification, characterization and indigo carmine degradation. Enzyme Microb. Technol. 41: 794-799.

27. Solden, D.M.; Dobson, A.D.; (2001). Differential regulation of laccase gene expression in Pleurotus sajor-caju. Microbiology 147: 17551763.

28. Tien, M.; Kirk, T.K. (1988). Lignin peroxidase of Phanerochaete chrysosporium. Meth. Enzymol. 161: 238-249.

29. Xiao, Y.Z.; Chen, Q.; Hang, J.; Shi, Y.Y. (2004). Selective induction, purification and characterization of a laccase isozyme from the basidiomycete Trametes sp. AH28-2. Mycologia 96 (1) 26-35. 